\title{
Theology of Independence as a Foundatioan of Developing Catholic Education in Indonesian Context According to Y. B. Mangunwijaya
}

\author{
Carolus Borromeus Mulyatno
}

Sanata Dharma University, Yogyakarta, Indonesia carlomul@gmail.com

\begin{abstract}
:
Education is one of the forms of the Indonesian Church's apostolate. In the context of Indonesia that fought for its independence, Y.B. Mangunwijaya affirmed the importance of theology of independence as an anthropological foundation of developing a liberating education. By using analytical descriptive method, this research focuses on finding the main ideas of YB. Mangunwijaya about theology of independence as a foundation of education and learning process at school. There are three important things found in this research. First, theology of independence is the right formula that unites Christian values and the struggle for national life. It bases on the movement of Jesus Christ that is inclusive and universal for the sake of a more human life. Second, theology of independence becomes the foundation to develop a child-centered learning to develop or liberate themselves exploratively, creatively and integrally. Third, in order to develop liberating education, teachers who love children and dare to explore with the children for optimal child development are needed. Y.B. Mangunwijaya's thoughts provide a foundation for reconstructing the vision, mission and praxis of Catholic education in Indonesia contextually for a more liberating national life.
\end{abstract}

\section{Keywords:}

theology of independence, children, liberating education, character, integral

\section{INTRODUCTION}

YB. Mangunwijaya (1929-1999) is a unique and talented person. Seventy years of his life journey are filled with many phenomenal works. 
He is known as a priest who was friendly with anyone from various interreligious groups, a unique architect, a charming humanist, a humanitarian fighter and a servant for the poor.

He was once a Student Soldier who fiercely fought for the Indonesian independence. After the war for independence ended, he entered the Seminary and chose to be a Catholic priest who was friendly with everyone. He was not satisfied just to be a servant of the people in the church, so he also served the poor in the valley of Code River, the victims of eviction in Kedung Ombo dam and the coastal communities of Grigak Beach, Wonosari, who often experienced drought in the dry season.

Being a priest is seen as a vocation to serve God and others in all aspects of life. Priesthood is a call to be one-hearted and in arms with the poor as fellow countrymen. Loving the country and defending the nation is manifested in an effort to fight for the dignity of all Indonesian people by respecting the diversity of religion, race, ethnicity, class and culture. Mangunwijaya's literary and architectural works are expressions and forms of his partiality to defend human dignity, especially those who are poor and marginalized. Literature, culture and education are the entry points to develop national values and solidarity among citizens in fulfilling the independence.

Mangunwijaya asserts that the rest of his life is devoted to developing elementary education as a way to defend human dignity. As a Catholic priest, he formulates a reflection of his faith (theology) in the Indonesian context as a foundation to develop a liberating education. What is meant by theology of independence? What is the relation between theology of indepenence and liberating education? How is a liberating learning process designed? The focus of this paper is to answer the three questions formulated above.

\section{TheOlogy OF INDEPENDENCE}

YB Mangunwijaya is known as a freedom fighter and a consistent defender of human dignity, especially for the poor and marginalized. The basis of his struggle is the Christian faith which he finds in the process of doing theology. He simply explains that theology has two models. ${ }^{1}$ First, theology is a reasonable accountability of faith which is made spon-

YB. Mangunwijaya, Manusia, pascamodern, Semestadan Tuhan: Renungan Filsafat Hidup Manusia Modern (Yogyakarta: Kanisius, 1999), 173. 
taneously. In the understanding of this theology model, every person who has faith can perform this theology. Most people are either consciously or unconsciously performing this theology to be accountable for their lives as a manifestation of their faith. Second, theology is a scientific effort to formulate their daily lives critically and systematically as a real form of their faith manifestation. Only a few people perform the second model of theology, namely the scientific theology. Therefore, the second model of theology is often said to be the actions of the elite. Both theological models have the same goal, which is the renewal or transformation of living together that can be understood as a process of liberation.

Performing theology spontaneously and or scientifically is a real manifestation of liberating lives from all the problems and shackles that hinder the dignified life as God's creation. Thus, performing theology has the purpose of liberating lives. He asserts:

All the attention to the legal system that is increasingly fair, all humanitarian efforts to help the poor and marginalized, the development of knowledge and human culture that defends the truth, and so on has the purpose to liberate humans from all forms of shackles: shackle of ignorance, injustice, lies, as well as muscle limitations, diseases, natural hazards and human habits that harm themselves; shackles of colonization and human exploitation by other humans, and so on. In the language of faith, it is the shackle of sin, which is everything that destroys the order of God so that humans become real and full human beings, personally and socially. The August 17, 1945 Proclamation and the struggle for economic and cultural liberation of the Indonesian people are inspired and strengthened by the theology of independence, whether consciously or unconsciously, spontaneously or reflectively. ${ }^{2}$

Y.B. Mangunwijaya gives a critical note on the theology of liberation that developed in the seventies in Latin America. Theology of liberation developed in the situation where people struggle to fight against the structural injustice that resulted in a process of impoverishment. Unjust and oppressive community structures made many people fall in the very poor social conditions. For this reason, a group of people of faith strives to explore the foundations of the Christian faith to liberate themselves from the oppression of the oppressive socio-political structures. Therefore, theology of liberation is like a drum of war against the social political forces that wante to maintain the status quo. Suspicion of the 
process of theology of liberation cannot be avoided ${ }^{3}$. There are many political rulers whose establishment is disturbed and then makes a fierce resistance to the theology of liberation movement. They give the stigma that those who performe theology of liberation are Marxist and communist ideologists.

In addition to being aware of the controversy over the theology of liberation movement, Y.B. Mangunwijaya asserts that the scope of the struggle for theology of independence is far broader than the theology of liberation. Theology of independence is far more radical and has a broader and more profound dimension than theology of liberation. Performing theology was a process of liberating ourselves from all the shackles of evil and human problems that affect human relations with others, nature and God. The human problems cover sin, disease, fear, oppression, alienation, poverty, and ignorance. The problem of poverty in the economic field that is related to an unjust socio-political structure is only a part of the human problems.

Theology of independence is not only an effort to liberate humans from the conditions of poverty and socio-political oppression, but also a positive effort to establish a harmonious, peaceful, just, brotherly and prosperous life system in an inner and outer order. Theology of independence derives from the belief that God wants human life to develop in its entirety. Theology of independence "has existed in the realization of the Almighty among the Hebrew since Prophet Abraham". ${ }^{4}$ Faith in God encourages humans to free themselves from all shackles and real problems that hinder the development of their lives in a dignified manner. However, the term independence has a much broader, deeper and more comprehensive meaning than the term liberation.

Although theology (logical accountability of faith) has to encourage a liberation process, a liberation movement cannot be justified when making use of frontal and revolutionary ways. The theology of liberation movement had already been understood narrowly as a resistance to the shackling political and economic system. The term liberation tends to be understood negatively and is associated with liberal things. Mangunwijaya brought back the meaning and understanding of theology as taught by Jesus Christ, namely theology of independence. In the context of Indonesian society who were struggling to fill in the independence, theo-

3 YB. Mangunwijaya, Manusia, pascamodern,...., 176.

4 Y.B.Mangunwijaya, Memuliakan Allah, Mengangkat Manusia (Yogyakarta: Kanisius, 1999), 113. 
logy of independence is a more contextual term and has the potential to unite all layers of society from different backgrounds of groups, religions and cultures to jointly build a prosperous and dignified nation.

The term independence puts more emphasis on the importance of the struggle to develop life as a whole. For this reason, the theology of independence in the Indonesian context pays attention to all efforts to transform all forms of shackles in life. ${ }^{5}$ What is meant by shackles are ignorance, injustice, lies, diseases, natural hazards and self-destructive habits, and human exploitation by other humans.

In Christian faith, Jesus Christ is the main inspiration for developing the theology of independence. Realizing true independence is the focus of Jesus' life. He heals the sick, feeds the hungry, liberates people from the shackles of evil and raises the dead. Christians continue Jesus' call and mission in theology of independence. Theology of independence is the process and struggle for the independence of the whole and true human being "from their profanity, cruelty, greed, and exploitation de l'homme par l'homme, no matter what their position, intelligence, ability, skin, nation or religion is" 6 . Theology of independence is a humane effort to understand, defend and fight for human dignity as a whole in all its dimensions in order to surpass all shackles and develop oneself as a whole.

Theology of independence departs from the experience and longing of the people in a society that is far from being independent in a complete sense. Theology is always characterized by independence because in a situation that is not yet whole and complete "everyone longs for liberation". ${ }^{7}$ In the Indonesian society, realization of faith is in the context of the struggle to liberate oneself from the pressure of various problems resulting from ignorance, poverty, injustice, and environmental destruction. Thus, theology is supposed to encourage for a fight for an increasingly independent life and be able to overcome all forms of injustice, ignorance and selfishness in order to realize the life of an increasingly dignified society. That is the movement made by Jesus and His disciples. Based on the example given by Jesus and the disciples, Y.B.Mangunwijaya emphasizes that the struggle for independence is identical with the process of humanizing human beings: "Be a good human being, humane

5 Y.B. Mangunwijaya, Manusia, pascamodern,...., 175.

6 Y.B. Mangunwijaya, Memuliakan Allah, Mengangkat Manusia, 113.

7 Y.B. Mangunwijaya, Manusia, pascamoder.,174. 
being, for humanity is the way to God". ${ }^{8}$ Raising human dignity is a way to glorify God.

Jesus lives in the midst of the poor and chooses to fight with small people, the poor and marginalized to free themselves from all shackles in order to realize a dignified and humane life. Jesus does not choose to make an ally with powerful parties or political rulers like Herod, the connoisseur of luxurious life ${ }^{9}$.

When Indonesia experienced a severe crisis in 1997, Mangunwijaya called for the importance of the Church to return to follow Jesus who "prioritized the poor who were oppressed and exploited, tortured and displaced, with all the consequences, together and in harmony with the people across religions" ${ }^{10}$. Faith has to be grounded through real work to realize the liberated and humane life altogether.

The theology of independence movement takes place very late indeed. Theological practices in the Church are dominated by the educated and the noble persons who affiliate with political authorities for so long, "business and the world of imperial colonial money". ${ }^{11}$ Marriage between religion and political power (dominator of cultural and economic power) occurred for almost seventeen centuries. The development of theology that has a character of being critical against the shackling domination was difficult to expect when the Church became a part of the dominator and the status quo. According to Mangunwijaya, after the Catholic Church was forced to separate from the political power in the 19th century, the Church was motivated to direct its life to "the essential purpose and task of the gentle, poor and suffering followers of Isa of Nazareth, as a consequence of His teachings about honesty, truth, justice, love, with a characteristic attitude of non-violence" ${ }^{12}$.In the context of Indonesian society in which Christians are minority and live in the religious, ethnical, racial and cultural diversity, theology of independence means the movement of every follower of Christ and the Christian community to give real testimony about the law of love manifested in a full of brotherhood, honesty, mutual help, fair and peaceful life. The

8 Y.B. Mangunwijaya, Memuliakan Allah,..., 21.

9 Y.B. Mangunwijaya, Gereja Diaspora (Yogyakarta: Kanisius, 1999), 31.

10 Y.B. Mangunwijaya, Gereja Diaspora, 32.

11 Y.B. Mangunwijaya, Manusia, pascamodern,..., 177.

12 Y.B. Mangunwijaya, Manusia, pascamodern, ..., 178. 
law of love becomes a force that is centered on efforts to answer human existence for an independent and dignified life. Thus, "the way to act should conform to the law or the way of existence or circumstances". ${ }^{13}$

There are five basic principles and attitudes that need to be fought for in a theology of independence ${ }^{14}$. First, theology of independence is a movement of struggle to sue and fight all forms of injustice. Second, theology of independence moves Christians to increase public awareness, especially the poor, of various forms of structures and mechanisms that result in poor communities. Third, theology of independence becomes effective when mobilizing poor people to fight and work together in developing their prosperity. Fourth, theology of independence is evident in the solidarity movement (working together) between all parties, namely intellectuals, people who are economically capable, clergy, Church leaders, educated people, volunteers, poor people and marginalized people. Fifth, theology of independenceis more successful when it involves a lot of poor people to establish a just and peaceful order of life so that when their standard of living increases, they do not hold a grudge that appears in the attitudes and behavior of oppressing the weaker people.

The movement of theology of independence becomes sustainable and fruitful when responsibility, attitude and behavior of mutual love in the community are realized ${ }^{15}$. Thus, theology of independence is a process of performing a theology that involves everyone to behave and act more responsibly in building a dignified life together. The scope of theology of independence is the broad society that works hand in hand in realizing "truth, honesty, justice, healing, love, independence, peace, and so on so that people and society are increasingly independent, humane, just, civilized, and realizing the will of God". ${ }^{16}$ By understanding theology as an independence movement, every person of faith and Christian community become increasingly responsible for developing community life with "sincerity, willingness, solidarity, kinship, and holiness between fellow brothers and sisters, so that it is more to organisms than organizations"17.

13 Y.B. Mangunwijaya, Gereja Diaspora, 37.

14 Y.B. Mangunwijaya, Memuliakan Allah, Mengangkat Manusia, 118.

15 Y.B. Mangunwijaya, Memuliakan Allah, Mengangkat Manusia, 121.

16 Y.B. Mangunwijaya, Manusia, Pascamodern,..., 179.

17 Y.B. Mangunwijaya, Gereja Diaspora, 100. 


\section{Liberating Education In The Indonesian ConteXT}

YB. Mangunwijaya sees clearly that Indonesian people really need an affirmation of their identity as an independent nation. ${ }^{18}$ For this reason, education is crucial to respond to the two needs of Indonesian independence. First, Indonesian people need educated generations to fight for the unity and affirm the identity of Indonesian people. Second, the improvement of the quality of the nation is only possible if there are equity and improvement of the quality of education throughout the country. One of the important pillars of education is the presence of teachers who truly dedicate their lives to help developthe children.

Since the closing of the School of Teacher Education (SPG) and the transformation of IKIP - teachers education institute - to University, Y.B. Mangunwijaya is very anxious. He worries about the future of Indonesian people. For him, SPG and IKIP are two institutions that contribute greatly to the education of qualified teachers. Real teachers are increasingly difficult to find. There are only trainers and children's instructors.

Mangunwijaya has been developing experimental Elementary Education to educate and assist teachers through child assistance practices. Kanisius Mangunan Elementary School, which never has a classroom and is closed, is revived to try out the basic education programs and ideas that liberated poor children. By educating poor children, teachers imporve their educational spirituality and capability in globalization era.

According to Mangunwijayaijaya, in Asia, "especially in Indonesia, the small, weak, poor people are generally not appreciated. Those who are valued are those who are rich and powerful; who can practically govern whatever they like “. ${ }^{19}$ Even though Indonesia bases its nation life on Pancasila and has the goal of building a just and civilized humanity, the poor people are often marginalized and have no defenders.

Mangunwijaya's main concern is the underprivileged children who have limited access to education. Mangunwijaya's inspiration for his struggle is "Jesus as a figure who has special attention to those who are sick, disabled, suffer from leprosy, wasted, and insulted by society". ${ }^{20}$ Building an independent life is a human duty that leads people to the

18 C.B. Mulyatno, "Pendidikan demi Manusia dan Bangsa" in Lembaga Pendidikan katolik dalam Konteks Indonesia, ad .(Yogyakarta: Kanisius, 2017), 277-294.

19 Y.B.Mangunwijaya, Memuliakan Allah,..., 18.

20 Y.B. Mangunwijaya, Memuliakan Allah, Mengangkat Manusia, 16. 
faith in the loving and merciful God ${ }^{21}$ For him, basic education is a mean to equip the poor children to be persons who have strong, creative and loyal characters. Education equippes children to possess self-confidence and the habit of helping each other to defend their dignity. From the experience of accompanying poor children, Mangunwijaya realizes that non-formal education has no guarantee of sustainability. Volunteers can come and go at any time. For this reason, he developes a formal education to figure out models, ways and praxis of basic education that are liberating so that they can inspire many educational activists.

The independence of the nation had been fought ferociously and was costly. Therefore, the nation's independence needs to be filled by independent children. High quality basic education is a way to liberate the nation's children so that they can become pioneers in developing the foundations of a humane and dignified national life. ${ }^{22}$ Most Indonesian children are still living in poverty. Thinking about the nation's future means having to care about the development of the high quality education for poor children.

Inspired by the pedagogy of the heart of Paulo Freire, Mangunwijaya makes basic education as a process that liberates children. Liberating education is child-centered and for the sake of the development of the children. Education is a space for children to fully explore themselves and actively exploring their creativity. Education is a means for humans which must be directed towards developing "character, world of attitude, solidarity, mentality, and spirituality". ${ }^{23}$ Therefore, the main requirement of being a teacher is the involvement of the heart to love and to guide the children in the process of their development.

The idea to develop basic education is also strengthened by the results of the research conducted by Prof. Dr. Theodor Hanf from Germany. Prof. Theodor emphasizes that Catholic education in Indonesia has failed to make a significant contribution to the formation of community mentality that united and brought prosperity ${ }^{24}$. From his experience of being involved in serving the poor people, Mangunwijaya sees that

21 Y.B. Mangunwijaya, Memuliakan Allah, Mengangkat Manusia, 21.

22 Tri Hartono, "Imam Bagi Kaum Tertindas", 36.

23 Y.B. Mangunwijaya, Pendidikan Pemerdekaan (Yogyakarta, DED-Miserior, 2005), 5.

24 Theodor Half, "Pendidikan di Negara Berkembang”, dalam Seri Forum LPPS No. 09:Mencari Pendidikan Alternatif dalam Karya-karya Pendidikan Katolik (Jakarta: LPPS-KWI, 1987), 5-10. 
Catholic schools in Indonesia have a low contribution to the development of the life quality of the nation's children, especially the poor ${ }^{25}$. Catholic schools tend to go with the flow of following the government policies. The low quality of education is caused by the unclear human vision, constantly changing curricula, low-quality teachers, a less conducive community climate and regulations that tend to be capitalistic, liberalistic and perpetuating the difference between groups. Education tends to side with the elites, for the sake of strengthening the elite groups, and not for educating the nation's children, especially the poor who are loyal, caring and prioritizing brotherhood.

For Mangunwijaya, education must be returned to the child, from the child and for the benefit of the child ${ }^{26}$. First, a child is a whole, multi-dimensional individual. Basic education is very important to develop his or her personal character as a whole. Children develop and are healthy in a logical, emotional, mental, moral, social, and spiritual manner in their own uniqueness in the frame of diversity of the Indonesian people. The tasks of the school and the teacher are to guide the children in developing themselves fully in a joyful atmosphere, full of brotherhood and mutual friendship. The school has a role to equip the children to be able to learn for the rest of their lives in developing their integrity as a unique and independent person but also to foster awareness and social care as the members of the community.

Second, the curriculum is the children themselves. By taking the symbolic tree of life, Mangunwijaya explained that curriculum is an organic unity of thought, taste and environmental intelligence. Tree roots represent history and geography as a foothold and a place for the identity and life orientation to grow. Tree trunks describe language, mathematics and science skills. The childrenarethe language that understands themselves and the realities of the natural surroundings and communicates them in living together. Leaves, flowers and fruit symbolize the potentials of expressing (art, sports, humanities) and skills that serve to equip a natural processing of life and the universe. Thus, curriculum is the children's potentials that need to be fostered into skills for thinking, being virtuous, working, empathizing in friendship and lifelong learning.

25 Y.B. Mangunwijaya, "Si Gajah dan Si Kancil: Mencari dan Mengembangkan Pendidikan Alternatif, Terutama Bagi Kaum Tersisih”, dalam Seri Forum LPPS No. 09:Mencari Pendidikan Alternatif dalam Karya-karya Pendidikan Katolik (Jakarta: LPPS-KWI, 1987), 15-23.

26 Y.B. Mangunwijaya, Pendidikan Pemerdekaan (Yogyakarta, DED-Miserior, 2005), 38-41 
Third, the main teacher is the child or the student him/herself. While the teacher outside the student is a child lover and facilitator who helps children to recognize all their talents. The teacher acts as a guide for the development of children in accordance with their own talents. The teacher facilitates children so that they like asking questions, seeking answers, doing adventures, being critical, creative and rich in imagination. The teacher is the child's motivator in finding the pleasure of learning so that the child becomes a lifelong learner, more independent learner, develops more fully and cares for others and the environment. Teachers are learning individuals who love children and are passionate in compassion and caring. In this sense, the teacher is a sister, brother, father, mother and friend for studying. ${ }^{27}$ Teachers are not authoritarian preachers and tyrannical instructors for children.

In Mangunwijaya's educational philosophy, Pancasila is symbolized as the sun that illuminates and energizes growth. ${ }^{28}$ Sunlight illuminates intelligence and sense so that children are able to understand themselves and the natural surroundings as unity in diversity. Pancasila is a religiosity that contains values like the sun that illuminates human life and the universe. Thus, Pancasila does not become abstract values which are indoctrinated, but a religiosity experienced in the whole learning process organically.

An organic and child-centered curriculum is the basis of active learning and experiential learning methods. Children are teachers who actively explore themselves creatively. They are active and happy learners and adventurers. School is a space that helps children to experience themselves as part of others and nature. At that time as well, children recognize diversity as well as equality as God's creation. Schools become learning spaces to recognize uniqueness, differences, the art of communicating and collaborating to solve problems that they are facing together. In this learning process, children develop the core of their religiosity, namely in the experience of mutual respect, acceptance, and love as well as a sense of responsibility and care for others. This is the essence of every religious teaching which reflects the values of Pancasila. Through an organic and integral learning, religious values and Pancasila make children love differences and diversity even more as the richness of national life. An organic child-centered curriculum that is oriented

\footnotetext{
27 Y.B. Mangunwijaya, Pendidikan Pemerdekaan, 107.

28 Y.B. Mangunwijaya, Pendidikan Pemerdekaan, 90.
} 
towards child development is a prerequisite for integral education that fosters character, culture, language, mastery of self-orientation, critical and skillful attitudes, cooperation and caring, and positive experiences in the nation's children. With an understanding and framework of thinking about organic curriculum originating from the children, the education process can integrate informal education in families and communities, non-formal education and formal education in schools. Educational philosophy like this is supposed to be the basis of every education reformation so that this nation's children are able to build Pancasila culture as a national character.

In the globalization era, children have to learn to deal with a rapidly changing world that undoubtedly carries overlapping problems. The provision received by children from formal schools despite the high level is never sufficient. Children need to be encouraged to explore in a purposeful manner for their own development. There are many problems that children will face in their daily lives. It is like there are too many fish that they have to catch. Therefore, the only way to catch so many fish (read: process problems), is by using nets as the right tool. Nets are not fishing rods or spears that catch the fish one by one. The net consists of lots of web-nets. The web-nets are mastery of language, but are equipped with the power and skills to ask questions, explore, investigate, research, question and seek answers by themselves. ${ }^{29}$

If a child likes exploration, he or she is naturally creative. Creative people are those who are not fixated on the patterns and roads that already exist, but those who find new ways ${ }^{30}$. Creative means dynamic and not easily stuck in a dead end. Even if they were stuck in a dead end, their creativity will find a way out. Their creativity will prevent them from despairing and make them spontaneously eager to find new ways to overcome problems that seem hopeless. That kind of attitude and courage are what children (especially from poor families) need for their future.

The children's power of exploration and creativity needs to get stronger affirmation. The strength of the power of exploration comes from the vision and attitude of a whole child. Integral or intact means many varieties that have a single structural arrangement organically. But even more deeply, the integral term here refers more to the attitude and na-

29 Y.B. Mangunwijaya, Pendidikan Pemerdekaan, 94.

30 Y.B. Mangunwijaya, Pendidikan Pemerdekaan, 38-9. 
ture of bravery and adept at finding alternative ways and tools. Thus, exploration and creation in integral self-development are characterized by the ability to think and behave nggiwar or dare to jump sideways, not just straight, to find new alternatives. ${ }^{31}$.

\section{A Liberating Learning}

Ki Hajar Dewantara and Adam Malik are two national figures who really inspire Mangunwijaya in developing a basic education. Adam Malik graduated from elementary school. However, he diligently developed his learning so that he could reach the level of community life whose influence was very important. He was never shackled by the limitations of formal education. ${ }^{32}$ Because of his perseverance in studying independently, he developed into a quality and independent individual who was once trusted to become a Minister, Vice President and UN official. Ki Hajar Dewantara was a national figure who inspired national, cultured education and emphasized the importance of teacher training in education. In Mangunwijaya's assessment, the education praxis in Indonesia is far from the inspiration of these two important figures.

In addition, Mangunwijaya also admires Socrates as one of the pioneers of the development of science. ${ }^{33}$ His life was identical to what philosophy means (loving wisdom) and knowledge. He did not write and pass on books on philosophy and knowledge. The only inheritance was an example to always ask. Socrates asked the political experts what politics was. He asked the cultural experts what culture was. He asked the education experts what education was. Socrates asked the experts in law about what law was. From Socrates, we learn that philosophy and science are firstly asking "what". The question "what" contains the will and effort to explore, search, investigate, and look into something so that senses reach the nature of reality. Reality or nature is knowledge and truth. Knowledge and truth are born from questions. Answers to questions will lead to new questions.

Socrates was remembered by his students not as a teacher who bequeaths knowledge and truth but a teacher who bequeaths a way of digging, pursuing, seeking, and finding truth through questions. The

\footnotetext{
31 Y.B. Mangunwijaya, Pendidikan Pemerdekaan, 98.

32 Y.B. Mangunwijaya, Pendidikan Pemerdekaan, 119.

33 Y.B. Mangunwijaya, Pendidikan Pemerdekaan, 35-6.
} 
method or way to seek and explore truth through questions is far more important than the truth. It could be said that through Socrates, God taught us how to find and seek truth and knowledge by asking "what".

Where is knowledge and truth discovered? That truth has been stored in the experience of human life. Truth is there in the peasants, teachers, parents, merchants, builders, political leaders, architects, clerics, priests, monks, etc. Truth and knowledge are also stored in the works of art, traditions and various habits of life in the society. When asking "what", we find out and move to reach the truth and knowledge. From the "what" question, we can detect one's interests and talents. A scientist is born from the question of "what" and the depth of knowledge is achieved in the process of answering the question and in raising new questions. The question "what" is the mother of all knowledge.

Basically, children already have the talent to ask. The task of parents and teachers is to create an atmosphere that allows children to be brave and happy to ask. First, parents and teachers need to create safe and pleasant relationships with the children. Second, children will be encouraged to ask questions about new things and those that interest them. Therefore, teachers and parents need to work together to create a natural, interesting and enjoyable atmosphere in the learning process and daily life. Various and natural teaching aids that are easily found around children are very helpful for children to sharpen their ability to ask questions. Third, teachers and parents need to classify various children's questions to recognize the children's talents and accompany and direct their development according to their talents. Formulating questions appropriately is far "more important than a thousand answers that exist but not necessarily appropriate" for children ${ }^{34}$.

Starting from how important it is to foster a sense of curiosity and the ability to ask, Mangunwijaya arrived at the belief in the importance of learning experimentation. In simple terms, what is meant by experimentation is a learning process that starts from the introduction of the potential of each child and is oriented towards the development of the child as a whole. This experimental learning process affirms the unique appreciation of child development in togetherness and unity in diversity in the spirit of solidarity as a nation. 
The learning process is based on the potential and core of the child's experience, namely religiosity that is rooted in the taste of Indonesian people ${ }^{35}$. Children are born and developed in Indonesian culture that uphold mutual cooperation (solidarity), brotherhood in diversity and liberation (the process of independence) as the core of Indonesian society's religiosity. Thus, education should develop the character of solidarity, brotherhood and independence in lifelong learning as the core of Indonesian humanity. The development of religiosity is very important for the affirmation of the identity of the nation. Religiosity learning is far more important than religion because in the context of Indonesian society, development in religion has been abundantly conducted in families, communities, and government programs. Through religiosity learning, children are facilitated to find a node that unites every religion that is very important for the nation's life.

One thing that is no less important in experimental learning is personal recognition and cura personalis (personal assistance) for the sake of self-development to be an explorative, creative and integral person in strong solidarity to build a quality life together. To realize the directed personal assistance, on target and in accordance with the needs of each individual to fully develop him/herself, early child introduction is very important. The child introduction focuses on getting a picture of the seven basic provision of a child's potential. ${ }^{36}$ Seven provisions or potentials of the children that need to be recognized are (i) character (religiosity values or attitude, obedience, mental and spiritual); (ii) language; (iii) orientation anddistinctive interests; (iv) science (mathematical abilities and logical thinking); (v) introduction to tools or devices in daily life; (vi) the ability to work in teams and involved in an organization; (vii) kinesthetic skill and physical health. These seven basic provisions can be explored through filling in questionnaires by the parents, interviews with the children or observing the children, records from previous schools, and exploring the children's data through communication between parents and teachers.

The results of the introduction are used as a starting point to design a learning with methods that are appropriate to the child's development needs and able to assist the child's learning process in the education process. The introduction was also used as a basis for observing the de-

35 Y.B. Mangunwijaya, Pendidikan Pemerdekaan, 4-5.

36 Y.B. Mangunwijaya, Pendidikan Pemerdekaan, 5-7. 
velopment of each child based on basic provision and the potential that had already been recognized. Early introduction and evaluation results are used as a starting point to make periodic assistance programs on an ongoing basis.

The ultimate goal of education is to improve the quality of humanity as a whole and to specifically increase the level of religiosity in each individual. Religiosity is the mother of "love of the truth, love for everything that is natural, simple, honest, true" ${ }^{37}$.In addition, in line with the thoughts of John B. Cobb, in the context of a plural society which is rich in religiosity values, education needs to develop the ability of each individual to be involved in developing cooperation in transforming the society. Children are increasingly able to realize their social responsibilities in their lives together in which they synergize and respect the uniqueness of each individual. The education process is not only based on appreciation for differences but also recognition of common concerns and ideals of living together. In the context of Indonesia which has a multicultural view, Bhineka Tunggal Ika, the implementation of liberating education creates and expands the critical dialogue spaces for children so that from early age they experience and value unity in diversity, love each other honestly and live in harmony to develop an independent national life.

\section{Concluding Remarks}

There are at least three important things that need to be underlined in developing the liberating education in this era. First, in the Indonesian context, formal (and non-formal) education must be oriented towards the development of human quality as a whole covering all aspects. Schools need to renew themselves and find their distinct characteristics in the context of Indonesia that is rich in culture and religiosity. Education is oriented towards developing human beings as a whole in solidarity, social care, and willingness to build a common life based on local cultural values. In other words, education is oriented towards developing inclusive religious enthusiasm in national life. ${ }^{38}$ When schools dissolve in the flow of public policy and do not present alternatives to the devel-

37 Y.B. Mangunwijaya, Menumbuhkan Sikap Religius Anak-anak (Jakarrta: Gramedia, 1986), 7.

38 Graham P. McDonough, "Bearers of Diverse Ecclesiologies: Imagining Catholic School Students as Informing a Broader Articulation of Catholic School Aims", Journal of Catholic Education, Vol 19, Issue 3, (2016) 83. 
opment of human quality in the life of the nation, schools will slowly but surely perish in the midst of competition.

Second, in the globalization era, schools that join competition with ranking systems, competition, prioritizing formalistic administration and ignoring personal approaches to children will be dragged into two extremes, namely to perish in the competition or to persist as an oppressive master. Constant competitions will present a group of winners or losers. In the spirit of Christian faith, victory is not measured by how many other people or groups are defeated but by how much love given for serving the poor and the marginalized in the spirit of compassion and mutual respect for differences. The measurement of the educational achievement is the improvement of the human quality as a whole which appears in the characters of brotherhood, solidarity, caring for others and nature, and being independent for lifelong learning.

In this competition era, the winners will concern themselves with the strategy for a bigger victory, while the losers will fall into the troubles and the losing. Individualism is getting stronger. It appears that most Catholic schools in Indonesia are schools that are losing in this competition era. As a result, each of them falls into the problems. Synergy and cooperation are not easy to build. In recent years, cooperation has been built not in order to find alternative models and affirmations of contributions to build the nation's unity and improve the quality of Indonesian human beings but to deal with the "common enemies" such as threats to religious lessons that are not suitable for the schools in Indonesia according to Mangunwijaya. In the context of Indonesia which is multi-cultural in nature, religiosity or the vibrancy of the heart that drives life to respect each other, love, help (working together), maintain harmony, and awe in all that is beautiful is more important for the unity of the nation than informative-formalistic religious teaching about dogma and worship ${ }^{39}$.

Third, in line with Mangunwijaya's struggle, schools managed by Catholic institutions and or people should be having Catholic characteristics. Catholicism in the Indonesian context is not superficially presented in religious symbols such as crucifix, Mary statues, and worships, but in universal religiosity and humanity values (Catholic: general) which unite all children in a spirit of solidarity, social responsibility, pride as Indonesian children and the joy of learning exploratively, creatively and integrally. Thus, Catholic schools are not trapped in a narrow-minded

39 Y.B. Mangunwijaya, Menumbuhkan Sikap Religius Anak-anak, 5. 
modern mentality that believes that the competition to master the intellectual science seems like a force to change the world ${ }^{40}$.

Considering that competition has the potential to foster violence and oppression, Catholic schools which are drowning in competition actually participate in the flow of violenceinstead of proclaiming the value of love. For this reason, education must be brought back to children. Children are the owners of education who must be helped to be self-sufficient and have a spirit of solidarity, brotherhood and independence in lifelong learning. Education should really play an active role in liberating the nation's children and improving the quality of life of the nation. In other words, Mangunwijaya highlights the role of education for developing intetral charaters of the childreen so that the are ready to be an active and creative actors of transforming soiciety. This idea is in line with the position of John Dewey and Paulo Freire. ${ }^{41}$

In order to build a quality Catholic visionary school, collaboration is needed to restore the school's orientation to humanitarian and national missions, as well as preparing qualified teachers (educators). The thing that also needs to be thought out and sought a way out together is to explore financial sources creatively to minimize the stigma that Catholic schools are factories to dredge people's money. Collaboration is a Chatolic School culture based on Chatolic values of love and bratherhood. The sense of community and collaboration is very important component of Catholic identity and in the same time it is a pillar of developing Chatolic School, ${ }^{42}$

40 Y.B. Mangunwijaya, Pendidikan Pemerdekaan, 14.

${ }^{41}$ Akello Specia and Ahmed A. Osman, "Education as a Practice of Freedom: Reflections on bell hooks", Journal of Education and Practice, Vol.6, No.17 ( 2015) 198.

42 Merylann "Mimi” J. Schuttloffel, "Catholic Identity: The Heart of Catholic Education”, Catholic Education A Journal of Inquiry and Practice, Vol. 16, No. 1 ( September 2012) 151. 


\section{BibLIOGRAPHY}

Cobb, John B., "Rethinking Christianity Faith in the Context of Religious Diversity", dalam The Dialogue Comes of Age: Christian Encounters with Other Traditions (ed.) John B. Cobb and Ward M. McAfee (Minneapolis: Fortrees Press, 2010).

Half, Theodor, "Pendidikan di Negara Berkembang", dalam Seri Forum LPPS No. 09:Mencari Pendidikan Alternatif dalam Karya-karya Pendidikan Katolik (Jakarta: LPPS-KWI, 1987), 5-10.

LPPS, Mencari Pendidikan Alternatif dalam Karya-karya Pendidikan Katolik (Jakarta: KWI, 1987).

Mangunwijaya, Y.B., Memuliakan Allah, Mengangkat Manusia(Yogyakarta: Kanisius, 1999).

Mangunwijaya, Y.B., Pendidikan Pemerdekaan (Yogyakarta: Dinamika Edukasi Dasar-Misserior, 2004).

Mangunwijaya, Y. B., Menumbuhkan Sikap Religius Anak-anak (Jakarrta: Gramedia, 1986).

Mangunwijaya, YB., Manusia, Pascamodern, Semesta dan Tuhan: Renungan Filsafat Hidup Manusia Modern (Yogyakarta: Kanisius, 1999).

Mangunwijaya, Y.B., Gereja Diaspora (Yogyakarta: Kanisius, 1999).

McDonough, Graham P., "Bearers of Diverse Ecclesiologies: Imagining Catholic School Students as Informing a Broader Articulation of Catholic School Aims", Journal of Catholic Education (Vol 19, Issue 3, 2016), 66-85.

Mulyatno, CB, "Keutamaan dalam karya-karya Kemanusiaan Y.B. Mangunwijaya”, Jurnal Teologi (No.2, Vol 2, Nopember, 2013), 185-198.

Mulyatno, CB., "Pendidikan demi Manusia dan Bangsa" dalam Lembaga Pendidikan katolik dalam Konteks Indonesia, (Yogyakarta: Kanisius, 2017), 277-294.

Specia, Akello and Ahmed A. Osman, "Education as a Practice of Freedom: Reflections on bell hooks", Journal of Education and Practice (Vol.6, No.17, 2015), $195=199$.

Schuttloffel, Merylann "Mimi” J., "Catholic Identity: The Heart of Catholic Education", Catholic Education: A Journal of Inquiry and Practice, Vol. 16, No. 1, September 2012), 148-154. 
Tri Hartono, "Imam Bagi Kavum Tertindas", dalam M. Purwatma (ed.), Romo Mangunwijaya: Imam bagi kaum Kecil (Yogyakarta: Kanisius, 2001), $29-44$.

Willi Pramudya, "Perjalanan Hidup Seorang Yusuf Bilyarta Mangunwijaya" dalam Th Sumarthana dkk (ed.), Mendidik Manusia Merdeka (Yogyakarta: Interfidei-Pustaka Pelajar, 1995), 3-19. 